\title{
REAKSI PASAR TERHADAP PENGUMUMAN CASH DIVIDEND PADA PERUSAHAAN YANG TERGABUNG DALAM INDEKS KOMPAS 100
}

\author{
I Putu Agus Ary Raditya Juliana ${ }^{1}$ \\ Ica Rika Candraningrat ${ }^{2}$ \\ ${ }^{1,2}$ Fakultas Ekonomi dan Bisnis Universitas Udayana (Unud), Bali, Indonesia \\ email: aryraditya12@gmail.com
}

\begin{abstract}
ABSTRAK
Tujuan penelitian ini adalah mengetahui reaksi pasar terhadap pengumuman cash dividend, dengan melihat perbedaan abnormal return dan trading volume activity sebelum dan sesudah pengumuman cash dividend. Pengumuman dividen merupakan peristiwa yang berpengaruh terhadap pasar, karena perusahaan memberikan informasi kepada publik. Informasi yang diberikan oleh perusahaan akan mempengaruhi pengambilan keputusan investor dan akan beraksi terhadap informasi tersebut. Sampel dari penelitian ini berjumlah 33 dari 100 perusahaan yang tergabung dalam indeks Kompas 100 di Bursa Efek Indonesia (BEI). Metode pengumpulan data menggunakan observasi non partisipan, yaitu observasi dokumen. Teknik analisis yang digunakan adalah Uji Paired-Sample T Test dan Uji Wilcoxon-Signed Rank Test. Hasil penelitian menunjukkan bahwa tidak ada perbedaan abnormal return serta trading volume activity sebelum dan sesudah pembagian cash dividend.

Kata kunci : cash dividend, abnormal return, trading volume activity
\end{abstract}

\begin{abstract}
The purpose of this study is to determine the market reaction to the announcement of cash dividends, by looking at differences in abnormal return and trading volume activity before and after the cash dividend announcement. Dividend announcement is an event that affects the market, because the company provides information to the public. Information provided by the company will influence investors' decision making and will act on that information. The sample of this study amounted to 33 of the 100 companies incorporated in the Kompas 100 index on the Indonesia Stock Exchange (IDX). The data collection method uses nonparticipant observation, which is document observation. The analysis technique used is Paired-Sample T Test and Wilcoxon-Signed Rank Test. The results showed that there were no differences in abnormal returns and trading volume activity before and after the distribution of cash dividends.

Keywords: cash dividend, abnormal return, trading volume activity
\end{abstract}




\section{PENDAHULUAN}

Pasar modal merupakan jembatan yang menghubungkan pemilik modal (investor) dengan peminjam dana yang disebut emiten atau perusahaan yang go public (Hermuningsih, 2012:2). Peranan pasar modal sangat penting dalam perekonomian negara, karena pasar modal merupakan alternatif pendanaan bagi perusahaan. Investor dapat menginvestasikan dananya di pasar modal dengan harapan mendapatkan keuntungan, sedangkan emiten atau pihak yang memerlukan dana dapat memperoleh dana di pasar modal untuk kegiatan operasional perusahaan.

Pasar modal (capital market) merupakan tempat diperjualbelikannya berbagai instrumen keuangan jangka Panjang, seperti utang, ekuitas (saham), instrumen derivatif, dan instrumen lainnya (Darmadji \& Fakhruddin, 2011:1). Salah satu instrumen investasi yang paling menarik adalah saham, karena saham memungkinkan investor untuk mendapatkan return atau keuntungan dalam jumlah besar. Namun, harga saham yang berfluktuasi juga dapat membuat investor mengalami kerugian dalam jumlah besar (Darmadji \& Fakhruddin, 2011:10).

Investor dituntut berhati-hati dalam berinvestasi saham, khususnya dalam pemilihan saham yang ingin diinvestasikan. Informasi merupakan hal penting yang harus diperhatikan oleh investor, karena informasi akan mempengaruhi keputusan investor dalam berinvestasi. Informasi yang umumnya diperhatikan oleh investor ataupun pihak-pihak yang terkait dengan pasar modal adalah corporate action. Corporate action merupakan aktivitas perusahaan yang mempengaruhi jumlah saham yang beredar dan berpengaruh terhadap harga saham di pasar, yang umumnya menarik perhatian pihak-pihak yang terkait di pasar modal, khususnya pemegang saham perusahaan (Darmadji \& Fakhruddin, 2011:139).

Corporate action harus mendapat persetujuan dalam RUPS (Rapat Umum Pemegang Saham) ataupun RUPSLB (Rapat Umum Pemegang Saham Luar Biasa), karena persetujuan dari pemegang saham adalah mutlak agar kegiatan perusahaan berjalan dengan efektif dan kebijakan yang diambil dapat dijalankan sesuai persetujuan pemegang saham. Kebijakan perusahaan yang umum dilakukan adalah kebijakan dividen, right issue, merger, bonus share dan stock split.

Kebijakan dividen adalah keputusan perusahaan untuk membagikan laba yang diperoleh perusahaan kepada pemegang saham dalam bentuk dividen ataupun ditahan dalam bentuk laba ditahan untuk pembiayaan investasi di masa yang akan datang (Sartono, 2010:281). Jenis pembagian dividen berdasarkan bentuk dividen yang dibayarkan ada dua jenis, yaitu cash dividend dan stock dividend. Cash dividend adalah dividen yang dibayarkan dalam bentuk tunai, sedangkan stock dividend adalah pembayaran dividen dalam bentuk saham yang dapat meningkatkan jumlah lembar saham dan menurunkan harga saham dengan proporsi seimbang yang mengakibatkan kekayaan pemegang saham tidak meningkat (Wiagustini, 2014:299).

Pembagian dividen diawali dengan pengumuman dividen. Hal tersebut merupakan faktor penting untuk mempengaruhi investor dalam berinvestasi (Pramana \& Abundanti, 2017). Pengumuman dividen adalah salah satu peristiwa yang berpengaruh terhadap pasar, karena perusahaan memberikan informasi kepada publik bahwa laba akan dibagikan kepada pemegang saham perusahaan. Informasi 
yang diberikan oleh perusahaan akan mempengaruhi pengambilan keputusan investor dan pasar akan beraksi terhadap informasi tersebut untuk mencapai harga ekuilibrium yang baru. Informasi atas peristiwa yang terjadi berkaitan dengan teori hipotesis pasar efisien yang menyatakan bahwa terbentuknya harga saham merupakan cerminan dari seluruh informasi yang ada (Jogiyanto, 2017:605).

Reaksi pasar terhadap informasi pengumuman dividen dapat diukur dengan dua indikator pengukuran yaitu abnormal return dan trading volume activity. Abnormal return digunakan untuk mengetahui reaksi investor terhadap informasi pengumuman dividen oleh perusahaan, sedangkan trading volume activity digunakan untuk melihat pengaruh pengumuman dividen terhadap volume perdagangan saham.

Penelitian tentang pengumuman dividen yang terkait dengan reaksi pasar dilakukan oleh Hannon et al. (2016) mendapat kesimpulan bahwa pasar bereaksi negatif terhadap dividen tunai setelah pengungkapannya. Chaudhary et al. (2016) menunjukkan bahwa pengumuman dividen menghasilkan sinyal pasar. Rosario \& Chavali (2016) menemukan bahwa pasar bereaksi positif terhadap pengumuman dividen. Chaabouni (2017) menunjukkan bahwa ada respons positif langsung dari harga saham terhadap pengumuman dividen. Namun, ada beberapa abnormal return tidak signifikan. (Majanga, 2015)menemukan bahwa pengumuman dividen memiliki hubungan positif dan signifikan terhadap harga saham.

Kaur (2018) menemukan bahwa pengumuman dividen menghasilkan pengembalian positif dan signifikan. Mrzygód \& Nowak (2017) menemukan bahwa terdapat reaksi pasar yang positif dan signifikan hanya pada hari pengumuman dividen dan satu hari setelah pengumuman dividen. Tran \& Mai (2015) menyatakan bahwa pengumuman dividen berdampak positif terhadap harga saham. Mikluš \& Oplotnik (2016) menunjukkan bahwa tidak ada kenaikan harga saham yang signifikan secara statistik dari kenaikan dividen. Harbi \& Bujang (2016) menyimpulkan bahwa pengumuman dividen memiliki efek signifikan terhadap pengembalian pasar saham. Kemal \& Kashif (2018) menemukan bahwa investor bereaksi terhadap perusahaan yang membagikan dividen karena memiliki pertumbuhan yang baik.

Waweru \& Otieno (2016) mendapatkan hasil yang menunjukkan bahwa pengumuman dividen berpengaruh signifikan terhadap pengembalian harga saham. Penurunan dividen menghasilkan pengembalian negatif sedangkan kenaikan dividen menghasilkan pengembalian positif. Darmawan (2018) menunjukkan bahwa dalam acara pengumuman dividen ditemukan reaksi yang signifikan dari pasar. Kayana et al. (2018) menyatakan bahwa tidak ada perbedaan yang signifikan terhadap abnormal return dan trading volume activity sebelum dan sesudah pengumuman dividen. Legenzova et al. (2017) dan Anwar et al. (2017) menemukan bahwa pengumuman dividen berdampak positif terhadap harga saham. Larimanu \& Suaryana (2015) menemukan bahwa pasar bereaksi positif terhadap pengumuman dividen. Widodo \& Nisful (2016) mengungkapkan bahwa pasar tidak bereaksi terhadap pengumuman dividen. 


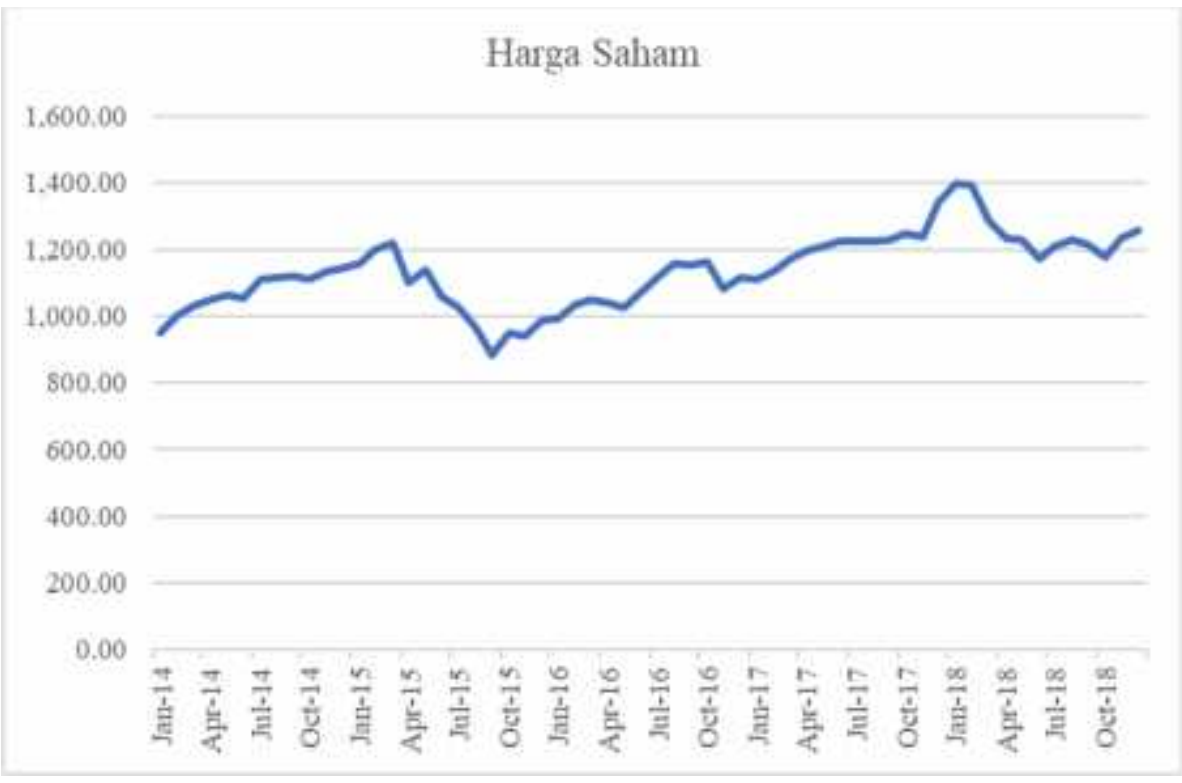

Gambar 1. Harga Saham Perusahaan yang Tergabung dalam Indeks Sumber : Data diolah, 2019 Kompas 100 di BEI Periode 2014-2018

Gambar 1. memperlihatkan fluktuasi harga saham pada perusahaan yang tergabung dalam indeks kompas 100, dimana dalam indeks tersebut tercatat perusahaan yang memiliki likuiditas yang baik dan membagikan dividen kepada pemegang saham perusahaan. Harga saham perusahaan cenderung meningkat setiap tahunnya, sehingga menarik untuk digunakan sebagai sampel dalam penelitian ini.

Penelitian sebelumnya menunjukkan hasil yang tidak konsisten, sehingga terdapat indikasi adanya research gap dan membuka peluang untuk diteliti kembali. Penelitian ini dilakukan untuk menguji reaksi pasar terhadap pengumuman cash dividend yang difokuskan pada abnormal return dan trading volume activity sebelum dan sesudah pengumuman cash dividend pada perusahaan Go-Public yang tercatat di Bursa Efek Indonesia. Penelitian dilakukan pada perusahaan yang terdaftar pada indeks Kompas 100 di Bursa Efek Indonesia karena harga saham yang terdaftar pada indeks Kompas 100 berfluktuasi dan cenderung meningkat setiap tahunnya. Berdasarkan latar belakang yang telah diuraikan, maka dilakukan pengujian kembali dengan rumusan masalah sebagai berikut: 1) Apakah terdapat perbedaan abnormal return saham sebelum dan sesudah pengumuman cash dividend? 2) Apakah terdapat perbedaan trading volume activity sebelum dan sesudah pengumuman cash dividend?

Berdasarkan rumusan masalah diatas, maka tujuan dari penelitian ini adalah: 1) Untuk mengetahui perbedaan abnormal return saham sebelum dan sesudah pengumuman cash dividend. 2) Untuk mengetahui perbedaan trading volume activity sebelum dan sesudah pengumuman cash dividend.

Penelitian ini diharapkan dapat memberikan kontribusi terhadap ilmu manajemen keuangan dan dapat memberikan bukti empiris mengenai abnormal return serta trading volume activity sebelum dan sesudah pengumuman cash 
dividend. Penelitian ini diharapkan dapat memberikan tambahan informasi bagi investor dalam pengambilan keputusan dalam berinvestasi pada perusahaan GoPublic serta dapat memberikan pertimbangan kepada perusahaan dalam pengambilan kebijakan untuk membagikan dividen.

Reaksi pasar terhadap pengumuman dividen dapat dilihat melalui perubahan penjualan dan harga. Perubahan harga akan mempengaruhi actual return saham melalui perubahan capital gain sehingga akan menimbulkan selisih antara expected return dengan return realisasi (abnormal return). Mengukur reaksi pasar terhadap peristiwa pengumuman dividen dapat dilakukan dengan cara mengukur abnormal return, apabila pengumuman dividen mengandung informasi maka pasar akan bereaksi sehingga terdapat abnormal return, sebaliknya jika pengumuman dividen tidak mengandung informasi maka pasar tidak akan bereaksi dan tidak terdapat abnormal return.

Hasil penelitian yang dilakukan oleh Aprilia \& Haryanto (2017)menemukan bahwa terdapat perbedaan abnormal return yang signifikan antara sebelum dan sesudah pengumuman cash dividend. Hannon et al. (2016) menemukan bahwa abnormal return berpengaruh negatif dan signifikan terhadap pengumuman cash dividend. Chaudhary et al. (2016) mendapatkan hasil abnormal return negatif disekitar jendela peristiwa, namun tetap positif dan signifikan secara statistik untuk hampir semua hari setelah tanggal pengumuman dividen. Legenzova et al. (2017) mengungkapkan bahwa abnormal return berpengaruh positif namun tidak signifikan terhadap peristiwa pengumuman dividen. Waweru \& Otieno (2016) menemukan bahwa abnormal return berpengaruh signifikan terhadap peristiwa pengumuman cash dividend. Kusno \& Hartanto (2018) menemukan bahwa terdapat perbedaan return sebelum dan setelah pengumuman dividen. Berdasarkan hasil tersebut maka diperoleh hipotesis sebagai berikut:

$\mathrm{H}_{1}$ : Terdapat perbedaan abnormal return yang sebelum dan sesudah peristiwa pengumuman dividen.

Volume perdagangan saham merupakan rasio jumlah lembar saham yang diperdagangkan pada waktu tertentu terhadap jumlah saham yang beredar pada waktu tertentu. Peristiwa pengumuman dividen berpengaruh atau tidak terhadap suatu saham dapat dilihat melalui volume perdagangannya, baik sebelum mapupun sesudah peristiwa pengumuman dividen. Trading volume activity (TVA) merupakan alat ukur yang dapat digunakan sebagai indikator pengukuran untuk mengetahui apakah peristiwa pengumuman dividen mempengaruhi reaksi pasar atau tidak. Kekuatan antara permintaan dan penawaran dapat dilihat dari volume perdagangan saham, hal tersebut merupakan cerminan dari perilaku investor di pasar modal.

Hasil penelitian yang dilakukan oleh Aprilia \& Haryanto (2017) menemukan bahwa tidak terdapat perbedaan trading volume activity yang signifikan antara sebelum dan sesudah pengumuman dividen kas. Kayana et al. (2018) dalam penelitiannya menemukan bahwa ada perbedaan pada trading volume activity yang signifikan sebelum dan sesudah pengumuman dividen tahun 2016, namun tidak ada perbedaan pada trading volume activity yang signifikan sebelum dan sesudah pengumuman dividen tahun 2017. Setiawan \& Bandi (2015) menyatakan bahwa trading volume activity menghasilkan reaksi pasar secara 
signifikan. Lavista et al. (2018) menemukan bahwa trading volume activity pada hari sebelum cum-dividend sampai saat dengan cum-dividend cenderung meningkat, tetapi turun pada hari sesudah cum-dividend. Berdasarkan hasil tersebut maka diperoleh hipotesis sebagai berikut:

$\mathrm{H} 2$ : Terdapat perbedaan trading volume activity (TVA) sebelum dan sesudah peristiwa pengumuman dividen.

\section{METODE PENELITIAN}

Penelitian ini termasuk ke dalam kategori event study atau studi peristiwa. Event study adalah studi yang mempelajari reaksi pasar terhadap peristiwa yang informasinya dipublikasikan, dan dapat digunakan untuk menguji kandungan informasi dari suatu pengumuman dalam bentuk setengah kuat. Penelitian ini dilakukan pada perusahaan-perusahaan yang membagikan dividen dan tergabung dalam indeks kompas 100 di Bursa Efek Indonesia (BEI) periode 2014-2018, dapat diakses melalui alamat www.idx.co.id. Bursa Efek Indonesia (BEI) dipilih karena kemudahan dalam memperoleh data yang diperlukan dan data-data yang diperoleh lebih akurat karena diawasi oleh Otoritas Jasa Keuangan (OJK).

Objek dalam penelitian ini adalah reaksi pasar terhadap peristiwa pengumuman cash dividend pada perusahaan-perusahaan yang tergabung dalam indeks kompas 100 di Bursa Efek Indonesia (BEI) periode 2014-2018. Berdasarkan rumusan masalah dan hipotesis yang telah diuraikan, maka variable yang dianalisis dalam penelitian ini yaitu abnormal return dan trading volume activity. Variabel tersebut akan diamati selama periode jendela 11 hari termasuk hari $\mathrm{h}$ pengumuman (5 hari sebelum, hari $\mathrm{h}$ dan 5 hari sesudah pengumuman cash dividend).

Abnormal return merupakan kelebihan dari return yang sesungguhnya terjadi terhadap return normal (Andini et al., 2017). Return realisasi yaitu hasil keuntungan yang telah terjadi dan dihitung berdasarkan data historis. Return sesungguhnya merupakan return yang terjadi pada waktu ke-t yang merupakan selisih harga sekarang relatif terhadap harga sebelumnya. Return realisasi dapat dihitung dengan rumus seperti berikut ini.

$R_{\mathrm{L} i}=\frac{P_{\mathrm{L}}-P_{\mathrm{L}}-1}{P_{\mathrm{L}}-1}$

Keterangan:

$\mathrm{R}_{\mathrm{it}} \quad=$ Return saham pada hari ke-t

$\mathrm{P}_{\mathrm{t}} \quad=$ Harga saham pada hari ke- $\mathrm{t}$

$\mathrm{P}_{\mathrm{t}-1} \quad=$ Harga saham pada hari ke $\mathrm{t}-1$

Expected return yaitu return yang diharapkan akan diperoleh Investor

di masa mendatang. Dalam penelitian ini, expected return dihitung menggunakan metode mean-adjusted model. Expected return dapat dihitung dengan rumus berikut ini.

$\mathrm{E}\left[R_{l, \tau}\right]=\frac{\sum_{j-[1]}^{[2} R_{L, j}}{T}$

$\mathrm{E}\left[K_{l, t}\right]=$ Expected return sekuritas ke-i pada periode peristiwa ke-t. 
$k_{l . j}=$ Return realisasi sekuritas ke-i pada periode estimasi ke-j.

$\mathrm{T}=$ Lamanya periode estimasi, yaitu $\mathrm{t} 1$ sampai dengan $\mathrm{t} 2$.

Abnormal return dapat dihitung menggunakan rumus berikut ini.

$A_{\mathrm{n}}=R_{\mathrm{li}}-E\left(K_{\mathrm{l}}\right)$

Keterangan:

$A \quad=$ Abnormal return saham i pada periode peristiwa ke-t.

$\boldsymbol{K}_{\mathrm{l} i} \quad=$ Return individual saham i sampai t.

$E\left(K_{\mathrm{Li}}\right)=$ Expected return saham saat $\mathrm{t}$.

Menghitung rata-rata abnormal return:

$C \quad l, t=\sum_{t=1}^{t} A$

Keterangan:

$C_{l, t}=$ Cumulative Abnormal Return sekuritas ke-I pada hari ke-t, yang diakumulasi dari abnormal return sekuritas ke-I mulai dari awal periode sampai hari ke-t.

A $\sharp \quad=$ Abnormal return untuk

Menghitung Trading Volume Activity

TVAi.t $=$\begin{tabular}{lllllllllll}
$s n a$ & $p$ & $n a$ & $l y$ & $d$ & & & $p$ & $w$ & $t$ \\
\hline$s i n a$ & $p$ & $n a$ & $y$ & $b$ & $p$ & $w$ & $t$
\end{tabular}

Keterangan:

TVA = Trading Volume Activity i pada waktu t.

i $\quad=$ Nama perusahaan.

$\mathrm{t} \quad=$ Waktu tertentu.

Menghitung rata-rata volume perdagangan saham

Rata-rata TVA $=\frac{\sum_{[-1}^{\mathrm{h}} T}{n}$

Keterangan:

$\mathrm{n} \quad=$ Sampel

TVAi $=$ Trading Volume Activity

Penelitian ini menggunakan event study untuk melakukan pengamatan pergerakan abnormal return dan trading volume activity dari hari ke hari dengan periode jendela peristiwa selama 11 hari. Penetapan peristiwa pengumuman dividen adalah $\mathrm{t}=0$, periode jendela peristiwa dibagi menjadi dua golongan yaitu $\mathrm{t}=5$ ( 5 hari sebelum pengumuman dividen) dan $\mathrm{t}=5$ ( 5 hari sesudah pengumuman dividen).

Populasi pada penelitian ini adalah perusahaan-perusahaaan yang terdaftar pada indeks Kompas 100 di Bursa Efek Indonesia (BEI), melakukan pengumuman dividen pada periode 2014-2018. Teknik pengambilan sampel dilakukan secara purposive sampling yaitu dengan membatasi pada perusahaan yang membagikan dividen selama tahun 2014 sampai dengan 2018 sebagai sampel penelitian. Sampel dalam penelitian ini berjumlah 33 sampel dari 100 populasi, berdasarkan kriteria yang sudah ditentukan. Tabel 1. menunjukkan daftar perusahaan sampel. 
Tabel 1.

Perusahaan dalam Indeks Kompas 100 yang Membagikan Cash Dividend Tahun 2014-2018

\begin{tabular}{|c|c|c|c|}
\hline No. & $\begin{array}{c}\text { Tanggal } \\
\text { Cum Date }\end{array}$ & Kode Saham & Nama Perusahaan \\
\hline 1 & $17 / 04 / 2018$ & AALI & Astra Agro Lestari Tbk. \\
\hline 2 & $30 / 04 / 2018$ & ADRO & Adaro Energy Tbk. \\
\hline 3 & $11 / 05 / 2018$ & AKRA & AKR Corporindo Tbk. \\
\hline 4 & $03 / 05 / 2018$ & ASII & Astra International Tbk. \\
\hline 5 & $12 / 04 / 2018$ & BBCA & Bank Central Asia Tbk. \\
\hline 6 & $27 / 03 / 2018$ & BBNI & Bank Negara Indonesia (Persero) Tbk. \\
\hline 7 & $29 / 03 / 2018$ & BBRI & Bank Rakyat Indonesia (Persero) Tbk. \\
\hline 8 & 02/04/2018 & BBTN & Bank Tabungan Negara (Persero) Tbk. \\
\hline 9 & 07/03/2018 & BJBR & Bank Pembangunan Daerah Jawa Barat dan Banten Tbk. \\
\hline 10 & $27 / 02 / 2018$ & BJTM & Bank Pembangunan Daerah Jawa Timur Tbk. \\
\hline 11 & $28 / 03 / 2018$ & BMRI & Bank Mandiri (Persero) Tbk. \\
\hline 12 & $04 / 07 / 2018$ & BMTR & Global Mediacom Tbk. \\
\hline 13 & $31 / 05 / 2018$ & CPIN & Charoen Pokphand Indonesia Tbk. \\
\hline 14 & $20 / 06 / 2018$ & CTRA & Ciputra Development Tbk. \\
\hline 15 & 03/07/2018 & GGRM & Gudang Garam Tbk. \\
\hline 16 & $07 / 05 / 2018$ & HMSP & HM Sampoerna Tbk. \\
\hline 17 & 08/06/2018 & ICBP & Indofood CBP Sukses Makmur Tbk. \\
\hline 18 & 08/06/2018 & INDF & Indofood Sukses Makmur Tbk. \\
\hline 19 & 04/07/2018 & INKP & Indah Kiat Pulp \& Paper Tbk. \\
\hline 20 & $30 / 05 / 2018$ & INTP & Indocement Tunggal Prakarsa Tbk. \\
\hline 21 & $02 / 04 / 2018$ & ITMG & Indo Tambangraya Megah Tbk. \\
\hline 22 & $21 / 06 / 2018$ & KLBF & Kalbe Farma Tbk. \\
\hline 23 & $07 / 06 / 2018$ & LSIP & PP London Sumatra Indonesia Tbk. \\
\hline 24 & $18 / 04 / 2018$ & PTBA & Bukit Asam Tbk. \\
\hline 25 & $03 / 07 / 2018$ & PWON & Pakuwon Jati Tbk. \\
\hline 26 & $02 / 07 / 2018$ & SCMA & Surya Citra Media Tbk. \\
\hline 27 & $07 / 03 / 2018$ & SMBR & Semen Baturaja (Persero) Tbk. \\
\hline 28 & $25 / 05 / 2018$ & SRIL & Sri Rejeki Ismail Tbk. \\
\hline 29 & 04/07/2018 & TKIM & Pabrik Kertas Tjiwi Kimia Tbk. \\
\hline 30 & $23 / 04 / 2018$ & UNTR & United Tractors Tbk. \\
\hline 31 & $31 / 05 / 2018$ & UNVR & Unilever Indonesia Tbk. \\
\hline 32 & $02 / 05 / 2018$ & WIKA & Wijaya Karya (Persero) Tbk. \\
\hline 33 & $13 / 04 / 2018$ & WSKT & Waskita Karya (Persero) Tbk. \\
\hline
\end{tabular}

Sumber: Data diolah, 2019

Metode pengumpulan data ini menggunakan observasi non partisipan, yaitu observasi dokumen dengan melakukan pengamatan data pada harga perdagangan saham. Data yang didapat berupa data sekunder yang diperoleh melalui website resmi Bursa Efek Indonesia melalui www.idx.co.id dan 
www.investing.com guna memperoleh informasi serta data yang diperlukan mengenai perusahaan yang melakukan pengumuman dividen.

Data kualitatif yaitu data yang berbentuk deskripsi, skema, dan gambar. Data kualitatif dalam penelitian ini adalah daftar nama perusahaan yang melakukan pengumuman dividen dan terdaftar di Bursa Efek Indonesia (BEI) periode 2014-2018. Data kuantitatif adalah data yang dapat dinyatakan dalam bentuk angka dan dapat diukur dengan satuan hitung. Data kuantitatif yang digunakan dalam penelitian ini diantaranya: a) Periode pengumuman dividen yang digunakan sebagai event date $\left(\mathrm{t}_{0}\right)$. b) Harga saham penutupan harian perusahaan yang melakukan pengumuman dividen dalam periode pengamatan, yaitu lima hari sebelum peristiwa pengumuman dividen, hari $\mathrm{H}$ dan lima hari sesudah peristiwa pengumuman dividen. c) Jumlah saham yang diperdagangkan secara harian. d) Jumlah saham yang beredar atau listed share. Sumber data dalam penelitian ini diperoleh dari situs www.idx.co.id dan www.investing.com.

\section{HASIL DAN PEMBAHASAN}

Pasar yang efisien ditekankan pada aspek informasi, artinya pasar dikatakan efisien apabila harga sekuritas mencapai harga keseimbangan baru akibat dari informasi yang masuk ke pasar. Pasar modal efisien adalah pasar di mana harga semua sekuritas yang diperdagangkan di pasar telah mencerminkan semua informasi yang tersedia, dalam hal ini meliputi informasi masa lalu, informasi saat ini serta informasi yang bersifat pendapat atau opini rasional yang beredar serta dapat memperngaruhi perubahan harga. Konsep dari pasar efisien menyiratkan adanya proses penyesuaian harga menuju harga keseimbangan yang baru. Efisiensi pasar didasarkan pada informasi harga atau nilai yang ada dari sekuritas, informasi tersebut dapat diperoleh secara cepat dan terbuka. Bursa Efek Indonesia (BEI) mengacu pada teori efisiensi pasar setengah kuat karena Bursa Efek Indonesia (BEI) adalah pasar yang harga atau nilai sekuritasnya mencerminkan informasi yang dipublikasikan perusahaan.

Studi peristiwa (event study) merupakan studi yang mempelajari reaksi pasar terhadap peristiwa yang informasinya dipublikasikan sebagai suatu pengumuman. Event study digunakan untuk menguji kandungan informasi dari suatu pengumuman dan dapat juga digunakan untuk menguji efisiensi pasar bentuk setengah kuat. Pengujian kandungan informasi bertujuan untuk melihat reaksi dari suatu pengumuman dengan melihat reaksi pasar pada waktu pengumuman diterima. Reaksi pasar ditunjukkan dengan adanya perubahan harga dari sekuritas bersangkutan dan dapat diukur dengan menggunakan return sebagai nilai perubahan harga atau dengan menggunakan abnormal return.

Teori yang digunakan dalam penelitian ini adalah Teori sinyal (signalling theory) yang merupakan tindakan yang dilakukan oleh manajemen perusahaan dengan memberikan petunjuk bagi investor tentang pandangan manajemen mengenai prospek perusahaan. Teori sinyal (signalling theory) 
menjelaskan dorongan perusahaan untuk memberikan informasi laporan keuangan kepada pihak eksternal. Dorongan perusahaan untuk memberikan informasi karena terdapat asimetri informasi antara perusahaan dan pihak luar karena perusahaan mengetahui lebih banyak mengenai perusahaan dan prospek yang akan datang daripada pihak luar (investor dan kreditor)

Tabel 2. menunjukkan nilai maksimum, minimum, rata-rata dan standar deviasi. Pada t-5 didapat nilai minimum sebesar -0.0426 oleh PT. Global Mediacom Tbk. (BMTR) dan nilai maksimum sebesar 0.1838 diperoleh oleh PT. Semen Baturaja (Persero) Tbk. (SMBR). Rata-rata abnormal return t-5 bernilai positif sebesar 0.003264 dan standar deviasi sebesar 0.0403766 . Pada t-4 didapat nilai minimum sebesar -0.0995 oleh PT. Semen Baturaja (Persero) Tbk. (SMBR) dan nilai maksimum sebesar 0.0640 diperoleh oleh PT. Charoen Pokphand Indonesia Tbk. (CPIN). Rata-rata abnormal return t4 bernilai negatif sebesar -0.008733 dan standar deviasi sebesar 0.0322994 .

Tabel 2.

Deskripsi Data Abnormal Return

\begin{tabular}{lrrrrr}
\hline & N & Minimum & Maximum & Mean & Std. Deviation \\
\hline $\mathrm{t}-5$ & 33 & -0.0426 & 0.1838 & 0.003264 & 0.0403766 \\
$\mathrm{t}-4$ & 33 & -0.0995 & 0.0640 & -0.008733 & 0.0322994 \\
$\mathrm{t}-3$ & 33 & -0.0477 & 0.0686 & 0.003633 & 0.0282793 \\
$\mathrm{t}-2$ & 33 & -0.0695 & 0.0405 & -0.009991 & 0.0257045 \\
$\mathrm{t}-1$ & 33 & -0.0852 & 0.0464 & 0.000212 & 0.0267634 \\
$\mathrm{t}$ & 33 & -0.0526 & 0.0834 & -0.003879 & 0.0267284 \\
$\mathrm{t}+1$ & 33 & -0.0631 & 0.0502 & -0.017564 & 0.0253059 \\
$\mathrm{t}+2$ & 33 & -0.0606 & 0.0790 & -0.007991 & 0.0319194 \\
$\mathrm{t}+3$ & 33 & -0.0505 & 0.0505 & 0.001385 & 0.0259818 \\
$\mathrm{t}+4$ & 33 & -0.0764 & 0.0496 & -0.000694 & 0.0240257 \\
$\mathrm{t}+5$ & 33 & -0.0664 & 0.0650 & -0.004655 & 0.0291179 \\
& 33 & & & & \\
Valid N & & & & & \\
(listwise) & & & & &
\end{tabular}

Sumber: Data diolah, 2019

Pada t-3 didapat nilai minimum sebesar -0.0477 oleh PT. Wijaya Karya (Persero) Tbk. (WIKA) dan nilai maksimum sebesar 0.0686 diperoleh oleh PT. Global Mediacom Tbk. (BMTR). Rata-rata abnormal return t-3 bernilai positif sebesar 0.003633 dan standar deviasi sebesar 0.0282793. Pada t-2 didapat nilai minimum sebesar -0.0695 oleh PT. Kalbe Farma Tbk. (KLBF) dan nilai maksimum sebesar 0.0405 diperoleh oleh PT. Indocement Tunggal Prakarsa Tbk. (INTP). Rata-rata abnormal return t-2 bernilai negatif sebesar -0.009991 dan standar deviasi sebesar 0.0257045 . 
Pada t-1 didapat nilai minimum sebesar -0.0852 oleh PT. Adaro Energy Tbk. (ADRO) dan nilai maksimum sebesar 0.0464 diperoleh oleh PT. Bank Negara Indonesia (Persero) Tbk. (BBNI). Rata-rata abnormal return t-1 bernilai positif sebesar 0.000212 dan standar deviasi sebesar 0.0267634. Pada $\mathrm{t}$ didapat nilai minimum sebesar -0.0526 oleh PT. Indah Kiat Pulp \& Paper Tbk. (INKP) dan nilai maksimum sebesar 0.0834 diperoleh oleh PT. HM Sampoerna Tbk. (HMSP). Rata-rata abnormal return $\mathrm{t}$ bernilai negatif sebesar -0.003879 dan standar deviasi sebesar 0.0267284 .

Pada $\mathrm{t}+1$ didapat nilai minimum sebesar -0.0631 oleh PT. Wijaya Karya (Persero) Tbk. (WIKA) dan nilai maksimum sebesar 0.0502 diperoleh oleh PT. Kalbe Farma Tbk. (KLBF). Rata-rata abnormal return $\mathrm{t}+1$ bernilai negatif sebesar -0.017564 dan standar deviasi sebesar 0.0253059. Pada $\mathrm{t}+2$ didapat nilai minimum sebesar -0.0606 oleh PT. Wijaya Karya (Persero) Tbk. (WIKA) dan nilai maksimum sebesar 0.0790 diperoleh oleh PT. Ciputra Development Tbk. (CTRA). Rata-rata abnormal return $\mathrm{t}+2$ bernilai negatif sebesar -0.007991 dan standar deviasi sebesar 0.0319194 .

Pada $\mathrm{t}+3$ didapat nilai minimum sebesar -0.0505 oleh PT. United Tractors Tbk. (UNTR) dan nilai maksimum sebesar 0.0505 diperoleh oleh PT. Sri Rejeki Ismail Tbk. (SRIL). Rata-rata abnormal return $\mathrm{t}+3$ bernilai positif sebesar 0.001385 dan standar deviasi sebesar 0.0259818. Pada $t+4$ didapat nilai minimum sebesar -0.0764 oleh PT. Wijaya Karya (Persero) Tbk. (WIKA) dan nilai maksimum sebesar 0.0496 diperoleh oleh PT. Indah Kiat Pulp \& Paper Tbk. (INKP). Rata-rata abnormal return $\mathrm{t}+4$ bernilai negatif sebesar -0.000694 dan standar deviasi sebesar 0.0240257. Pada $t+5$ didapat nilai minimum sebesar -0.0664 oleh PT. Kalbe Farma Tbk. (KLBF) dan nilai maksimum sebesar 0.0650 diperoleh oleh PT. Wijaya Karya (Persero) Tbk. (WIKA). Rata-rata abnormal return $\mathrm{t}+5$ bernilai negatif sebesar -0.004655 dan standar deviasi sebesar 0.0291179 .

Tabel 3.

Deskripsi data Trading Volume Activity

\begin{tabular}{|c|c|c|c|c|c|}
\hline & $\mathbf{N}$ & Minimum & Maximum & Mean & Std. Deviation \\
\hline$t-5$ & 33 & 0.000184 & 0.034247 & 0.00240067 & 0.006009215 \\
\hline $\mathrm{t}-4$ & 33 & 0.000063 & 0.042972 & 0.00245876 & 0.007337973 \\
\hline$t-3$ & 33 & 0.000030 & 0.025414 & 0.00204146 & 0.004416054 \\
\hline$t-2$ & 33 & 0.000012 & 0.017927 & 0.00171652 & 0.003090335 \\
\hline$t-1$ & 33 & 0.000013 & 0.025517 & 0.00195294 & 0.004396508 \\
\hline $\mathrm{t}$ & 33 & 0.000013 & 0.017628 & 0.00203864 & 0.003167244 \\
\hline$t+1$ & 33 & 0.000022 & 0.019183 & 0.00199170 & 0.003389086 \\
\hline$t+2$ & 33 & 0.000016 & 0.021733 & 0.00211727 & 0.004062465 \\
\hline$t+3$ & 33 & 0.000015 & 0.022099 & 0.00217179 & 0.003974782 \\
\hline$t+4$ & 33 & 0.000015 & 0.037945 & 0.00233621 & 0.006539280 \\
\hline \multirow[t]{2}{*}{$\mathrm{t}+5$} & 33 & 0.000008 & 0.046274 & 0.00280027 & 0.007972100 \\
\hline & 33 & & & & \\
\hline Val & & & & & \\
\hline
\end{tabular}

Sumber: Data diolah, 2019 
Tabel 3. menunjukkan nilai maksimum, minimum, rata-rata dan standar deviasi. Pada t-5 didapat nilai minimum sebesar 0.000184 oleh PT. Bank Central Asia Tbk. (BBCA) dan nilai maksimum sebesar 0.034247 diperoleh oleh PT. Pabrik Kertas Tjiwi Kimia Tbk. (TKIM). Rata-rata trading volume activity t-5 bernilai positif sebesar 0.00240067 dan standar deviasi sebesar 0.006009215 .

Pada t-4 didapat nilai minimum sebesar 0.000063 oleh PT. Semen Baturaja (Persero) Tbk. (SMBR) dan nilai maksimum sebesar 0.042972 diperoleh oleh PT. Pabrik Kertas Tjiwi Kimia Tbk. (TKIM). Rata-rata trading volume activity t-4 bernilai positif sebesar 0.00245876 dan standar deviasi sebesar 0.007337973. Pada t-3 didapat nilai minimum sebesar 0.000030 PT. Semen Baturaja (Persero) Tbk. (SMBR) dan nilai maksimum sebesar 0.025414 diperoleh oleh PT. Pabrik Kertas Tjiwi Kimia Tbk. (TKIM). Rata-rata trading volume activity $\mathrm{t}-3$ bernilai positif sebesar 0.00204146 dan standar deviasi sebesar 0.004416054. Pada t-2 didapat nilai minimum sebesar 0.000012 oleh PT. Semen Baturaja (Persero) Tbk. (SMBR) dan nilai maksimum sebesar 0.017927 diperoleh oleh PT. Pabrik Kertas Tjiwi Kimia Tbk. (TKIM). Rata-rata trading volume activity $\mathrm{t}-2$ bernilai positif sebesar 0.00171652 dan standar deviasi sebesar 0.003090335 .

Pada t-1 didapat nilai minimum sebesar 0.000013 oleh PT. Semen Baturaja (Persero) Tbk. (SMBR) dan nilai maksimum sebesar 0.025517 diperoleh oleh PT. Pabrik Kertas Tjiwi Kimia Tbk. (TKIM). Rata-rata trading volume activity $\mathrm{t}-1$ bernilai positif sebesar 0.00195294 dan standar deviasi sebesar 0.004396508. Pada t didapat nilai minimum sebesar 0.000013 oleh PT. Semen Baturaja (Persero) Tbk. (SMBR) dan nilai maksimum sebesar 0.017628 diperoleh oleh PT. Pabrik Kertas Tjiwi Kimia Tbk. (TKIM). Rata-rata trading volume activity $t$ bernilai positif sebesar 0.00203864 dan standar deviasi sebesar 0.003167244. Pada $t+1$ didapat nilai minimum sebesar 0.000022 oleh PT. Semen Baturaja (Persero) Tbk. (SMBR) dan nilai maksimum sebesar 0.019183 diperoleh oleh PT. Pabrik Kertas Tjiwi Kimia Tbk. (TKIM). Rata-rata trading volume activity $t+1$ bernilai positif sebesar 0.00199170 dan standar deviasi sebesar 0.003389086 .

Pada t+2 didapat nilai minimum sebesar 0.000016 oleh PT. Semen Baturaja (Persero) Tbk. (SMBR) dan nilai maksimum sebesar 0.021733 diperoleh oleh PT. Pabrik Kertas Tjiwi Kimia Tbk. (TKIM). Rata-rata trading volume activity $\mathrm{t}+2$ bernilai positif sebesar 0.00211727 dan standar deviasi sebesar 0.004062465. Pada $t+3$ didapat nilai minimum sebesar 0.000015 oleh PT. Semen Baturaja (Persero) Tbk. (SMBR) dan nilai maksimum sebesar 0.022099 diperoleh oleh PT. Pabrik Kertas Tjiwi Kimia Tbk. (TKIM). Rata-rata trading volume activity $\mathrm{t}+3$ bernilai positif sebesar 0.00217179 dan standar deviasi sebesar 0.003974782 .

Pada $\mathrm{t}+4$ didapat nilai minimum sebesar 0.000015 oleh PT. Semen Baturaja (Persero) Tbk. (SMBR) dan nilai maksimum sebesar 0.037945 diperoleh oleh PT. Pabrik Kertas Tjiwi Kimia Tbk. (TKIM). Rata-rata trading volume activity $\mathrm{t}+4$ bernilai positif sebesar 0.00233621 dan standar 
deviasi sebesar 0.006539280. Pada $t+5$ didapat nilai minimum sebesar 0.000008 oleh PT. Semen Baturaja (Persero) Tbk. (SMBR) dan nilai maksimum sebesar 0.046274 diperoleh oleh PT. Pabrik Kertas Tjiwi Kimia Tbk. (TKIM). Rata-rata trading volume activity $\mathrm{t}+5$ bernilai positif sebesar 0.00280027 dan standar deviasi sebesar 0.007972100 .

Tabel 4.

Hasil uji normalitas abnormal return sebelum dan sesudah pengumuman cash dividend one-sample kolmogorov-smirnov test

\begin{tabular}{llrr}
\hline & & $\begin{array}{c}\text { Abnormal } \\
\text { Return } \\
\text { Sebelum }\end{array}$ & $\begin{array}{c}\text { Abnormal } \\
\text { Return Sesudah }\end{array}$ \\
\hline $\mathrm{N}$ & Mean & 33 & 33 \\
Normal Parameters ${ }^{\mathrm{a}, \mathrm{b}}$ & Std. Deviation & -0.002327 & -0.005561 \\
& Absolute & 0.0124162 & 0.0116905 \\
Most Extreme Differences & Positive & 0.099 & 0.100 \\
& Negative & 0.072 & 0.100 \\
& & -0.099 & -0.067 \\
Test Statistic & & 0.099 & 0.100 \\
Asymp. Sig. (2-tailed) & & $.200^{\mathrm{c}, \mathrm{d}}$ & $.200^{\mathrm{c}, \mathrm{d}}$ \\
\hline
\end{tabular}

Sumber: Data diolah, 2019

Tabel 4. menunjukkan bahwa data berdistribusi normal, hal tersebut dapat dilihat dari nilai Asymp. Sig (2-tailed) abnormal return sebelum dan sesudah peristiwa pengumuman cash dividend bernilai lebih besar dari level of signifikansi $\alpha=5 \%(0.200>0.05)$ sehingga alat uji hipotesis yang digunakan adalah uji paired-samples $T$ test.

Tabel 5. menunjukkan bahwa data berdistribusi tidak normal, hal tersebut dapat dilihat dari nilai Asymp. Sig (2-tailed) trading volume activity sebelum dan sesudah peristiwa pengumuman cash dividend bernilai lebih kecil dari level of signifikansi $\alpha=5 \%(0.000<0.05)$ sehingga alat uji hipotesis yang digunakan adalah uji non parametrik Wilcoxon Signed Rank Test.

Pengujian hipotesis dalam penelitian ini menggunakan Paired-samples $T$ test. Berdasarkan hasil pengolahan pada Tabel 6 , didapat rata - rata hasil pengujian Sig (2-tailed) $0.292>0.05$. Hasil Pengujian SPSS menunjukkan tidak ada perbedaan yang signifikan antara abnormal return saham sebelum dan sesudah peristiwa pengumuman cash dividend disepanjang periode pengamatan. Hasil pengujian juga menyimpulkan bahwa $\mathrm{H}_{0}$ diterima dan $\mathrm{H}_{1}$ ditolak.

Berdasarkan hasil uji hipotesis tersebut didapatkan signifikansi $0.292>$ 0.05 sehingga diperoleh bahwa $\mathrm{H}_{0}$ diterima atau rata-rata abnormal return sebelum dan sesudah peristiwa pengumuman cash dividend tidak terdapat peredaan yang signifikan, maka $\mathrm{H}_{1}$ ditolak. 
Tabel 5.

Hasil uji normalitas trading volume activity sebelum dan sesudah pengumuman trading volume activity one-sample kolmogorov-smirnov test

\begin{tabular}{|c|c|c|c|}
\hline & & $\begin{array}{l}\text { Trading } \\
\text { Volume } \\
\text { Activity } \\
\text { Sebelum } \\
\end{array}$ & $\begin{array}{c}\text { Trading } \\
\text { Volume } \\
\text { Activity Setelah }\end{array}$ \\
\hline $\mathrm{N}$ & & 33 & 33 \\
\hline \multirow[t]{2}{*}{ Normal Parameters ${ }^{\mathrm{a}, \mathrm{b}}$} & Mean & 0.00211412 & 0.00224261 \\
\hline & Std. Deviation & 0.004971685 & 0.004713732 \\
\hline \multirow[t]{3}{*}{ Most Extreme Differences } & Absolute & 0.341 & 0.318 \\
\hline & Positive & 0.340 & 0.310 \\
\hline & Negative & -0.341 & -0.318 \\
\hline Test Statistic & & 0.341 & 0.318 \\
\hline Asymp. Sig. (2-tailed) & & $.000^{\mathrm{c}}$ & $.000^{\mathrm{c}}$ \\
\hline
\end{tabular}

Sumber: Data diolah, 2019

Tabel 6.

Uji Paired-Samples T-Test Abnormal Return

\begin{tabular}{cc}
\hline Paired Differences \\
\hline 95\% Confidence \\
Interval of the \\
Difference
\end{tabular}

Std.

\begin{tabular}{|c|c|c|c|c|c|c|c|c|c|}
\hline & & Mean & $\begin{array}{c}\text { Std. } \\
\text { Deviation }\end{array}$ & $\begin{array}{l}\text { Std. } \\
\text { Error } \\
\text { Mean }\end{array}$ & Lower & Upper & $\mathbf{t}$ & df & $\begin{array}{l}\text { Sig. } \\
\text { (2- } \\
\text { tailed) }\end{array}$ \\
\hline $\begin{array}{c}\text { Pair } \\
1\end{array}$ & $\begin{array}{l}\text { Abnormal } \\
\text { Return } \\
\text { Sebelum - } \\
\text { Abnormal } \\
\text { Return } \\
\text { Sesudah }\end{array}$ & 0.0032 & 0.0173 & 0.0030 & -0.0029 & 0.0094 & 1.072 & 32 & 0.292 \\
\hline
\end{tabular}

Pengujian hipotesis dalam penelitian ini menggunakan uji non parametrik Wilcoxon Signed Rank Test. Berdasarkan hasil pengolahan pada Tabel 7. menunjukkan rata-rata hasil pengujian Sig (2-tailed) $0.936>0.05$. Hasil Pengujian SPSS menunjukkan tidak ada perbedaan yang signifikan antara trading volume activity saham sebelum dan sesudah peristiwa pengumuman cash dividend disepanjang periode pengamatan. Hasil pengujian juga menyimpulkan bahwa $\mathrm{H}_{0}$ diterima dan $\mathrm{H}_{1}$ ditolak.

Berdasarkan hasil uji hipotesis yang dilakukan tersebut didapatkan signifikansi $0.936>0.05$ sehingga diperoleh bahwa $\mathrm{H}_{0}$ diterima atau ratarata trading volume activity sebelum dan sesudah peristiwa pengumuman cash dividend tidak terdapat peredaan yang signifikan, maka $\mathrm{H}_{1}$ ditolak. 
Tabel 7.

Uji Wilcoxon Signed Rank Test Trading Volume Activity (TVA)

Trading Volume Activity

Setelah - Trading Volume

Activity Sebelum

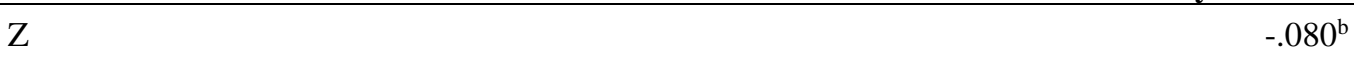

Asymp. Sig. (2-tailed) 0.936

Sumber: Data diolah, 2019

Hipotesis $1\left(\mathrm{H}_{1}\right)$ menyatakan bahwa terdapat perbedaan abnormal return yang sebelum dan sesudah peristiwa pengumuman dividen. Namun berdasarkan analisis, diperoleh nilai signifikansi $0.292>0.05$, hasil tersebut menunjukkan bahwa tidak ada perbedaan yang signifikan antara rata-rata abnormal return sebelum dan sesudah pengumuman cash dividend. Pembagian cash dividend kepada pemegang saham merupakan berita baik bagi investor, karena investor mendapat keuntungan berupa cash dividend dari kepemilikan saham yang dimiliki. Namun, dari hasil pengujian hipotesis dengan SPSS didapat bahwa investor tidak bereaksi terhadap pengumuman dividen karena tidak ada perubahan harga saham yang signifikan.

Investor di Indonesia dapat dibagi menjadi dua tipe, yaitu tipe trader dan tipe investor. Tipe trader biasanya melakukan trading untuk mendapatkan keuntungan jangka pendek berupa capital gain (selisih positif harga beli dan harga jual saham), sedangkan tipe investor biasanya melakukan investasi untuk mendapatkan keuntungan jangka panjang dengan melihat nilai intrinsik dan prospek perusahaan di masa depan. Investor di Indonesia memiliki kecenderungan sebagai trader karena psikologi investor Indonesia yang ingin mendapatkan keuntungan dengan cepat dan dana yang dimiliki terbatas. Tipe trader biasanya cenderung menginginkan capital gain karena menghasilkan keuntungan lebih banyak dibandingkan cash dividend, sehingga menyebabkan tidak terjadi reaksi pasar yang menyebabkan perubahan harga saham sebagai akibat dari respon investor.

Tidak terjadi perubahan harga saham mengindikasikan bahwa pasar modal di Indonesia tidak dalam kondisi setengah kuat, yang dimana harga sekuritas mencerminkan informasi masa lalu dan informasi yang dipublikasikan saat ini sehingga mempengaruhi aliran kas di masa mendatang.

Hasil penelitian ini mendukung penelitian yang dilakukan oleh Mikluš \& Oplotnik (2016) memperoleh hasil bahwa tidak ada kenaikan harga saham yang signifikan secara statistik dari kenaikan dividen. Kayana et al. (2018) memperoleh hasil bahwa tidak ada perbedaan yang signifikan terhadap abnormal return sebelum dan sesudah pengumuman dividen. Widodo \& Nisful (2016) memperoleh hasil bahwa pasar tidak bereaksi terhadap pengumuman dividen.

Hipotesis $2\left(\mathrm{H}_{2}\right)$ menyatakan bahwa terdapat perbedaan trading volume activity (TVA) sebelum dan sesudah peristiwa pengumuman cash dividend. Namun berdasarkan analisis, diperoleh nilai signifikansi $0.936>0.05$. hasil tersebut menunjukkan bahwa tidak terdapat perbedaan trading volume activity sebelum dan sesudah pengumuman cash dividend. Hipotesis ini tidak mendukung teori signal 
(signalling theory) yang menjelaskan dorongan perusahaan untuk memberikan informasi laporan keuangan kepada pihak eksternal.

Dorongan perusahaan untuk memberikan informasi karena terdapat asimetri informasi antara perusahaan dan pihak luar karena perusahaan mengetahui lebih banyak mengenai perusahaan dan prospek yang akan datang daripada pihak luar (investor dan kreditor). Namun, dalam penelitian ini investor tidak mengambil keputusan untuk melakukan transaksi dari pengumuman cash dividend yang dilakukan oleh perusahaan. Hal ini disebabkan karena sinyal berupa informasi pengumuman cash dividend yang dikeluarkan oleh perusahaan telah diketahui oleh investor, sehingga investor yang sudah memiliki saham di perusahaan tersebut tidak mengambil keputusan menjual sahamnya untuk mendapatkan cash dividend karena informasi tersebut menjadi berita bagus (good news) bagi investor yang sudah berinvestasi di perusahaan yang akan membagikan cash dividend tersebut. Investor yang kurang sensitif terhadap informasi dari pengumuman cash dividend, mengindikasikan bahwa investor kurang tertarik dengan return saham berupa dividen dan lebih memilih capital gain sebagai return dari investasi yang dilakukan.

Hasil penelitian ini mendukung penelitian yang dilakukan oleh Aprilia \& Haryanto (2017) memperoleh hasil bahwa tidak terdapat perbedaan trading volume activity yang signifikan antara sebelum dan sesudah pengumuman dividen kas. Kayana et al. (2018) memperoleh hasil bahwa tidak ada perbedaan pada trading volume activity yang signifikan sebelum dan sesudah pengumuman dividen tahun 2017. Stefanus \& Esra (2016) memperoleh hasil bahwa tidak terdapat perbedaan volume saham sebelum dan sesudah pengumuman dividen.

Berdasarkan pembahasan dari hasil penelitian, maka implikasi dari penelitian ini adalah Abnormal return merupakan kelebihan dari return yang sesungguhnya terjadi terhadap return normal. Abnormal return berguna untuk melihat besarnya pengaruh peristiwa terhadap harga saham. Hasil penelitian ini menunjukkan bahwa pasar tidak bereaksi terhadap pengumuman cash dividend yang dilakukan oleh perusahaan, sehingga tidak terjadi perubahan harga saham yang signifikan antara sebelum dan sesudah pengumuman cash dividend. Hasil penelitian ini mengindikasikan implikasi bahwa pasar modal Indonesia tidak efisien, hal tersebut dapat dilihat dari tidak adanya perubahan harga saham yang signifikan antara sebelum dan sesudah pengumuman cash dividend.

Trading Volume Activity merupakan rasio antara jumlah lembar saham yang diperdagangkan pada waktu tertentu terhadap jumlah lembar saham yang beredar pada periode waktu tersebut. Trading volume activity digunakan sebagai indikator untuk melihat likuiditas suatu saham sebelum dan sesudah pengumuman cash dividend. Hasil penelitian ini menunjukkan bahwa tidak terdapat perbedaan trading volume activity yang signifikan sebelum dan sesudah pengumuman cash dividend. Hal ini menandakan bahwa pasar tidak bereaksi terhadap pengumuman cash dividend. Hasil penelitian ini mengindikasikan implikasi bahwa pasar modal Indonesia tidak 
efisien dan sinyal yang diberikan perusahaan berupa pembagian cash dividend tidak diterima baik oleh investor.

\section{SIMPULAN}

Berdasarkan hasil analisis dan pembahasan yang telah dipaparkan sebelumnya, maka dapat diambil kesimpulam yaitu Hasil pengujian abnormal return saham sebelum dan sesudah peristiwa pengumuman cash dividend menunjukkan bahwa tidak ada perbedaan abnormal return sebelum dan sesudah pembagian cash dividend. Hasil penelitian ini menunjukkan bahwa pembagian cash dividen tidak direspon oleh investor karena dinilai sebagai bad news. Hasil penelitian ini tidak mendukung teori pasar efisien. Hasil pengujian trading volume activity saham sebelum dan sesudah pengumuman cash dividend menunjukkan bahwa tidak ada perbedaan trading volume activity yang signifikan sebelum dan sesudah pengumuman cash dividend. Tidak adanya reaksi investor atas pengumuman cash dividend membuat tidak ada perbedaan trading volume activity sebelum dan sesudah pengumuman cash dividend. Hasil penelitian ini tidak mendukung teori sinyal (signalling theory).

Berdasarkan hasil penelitian dan simpulan diatas, maka saran yang dapat diberikan adalah Bagi investor, sebaiknya tidak membeli saham perusahaan menjelang pengumuman cash dividend atau sesudah pengumuman cash dividend karena peluang untuk memperoleh return terbilang kecil. Sebaiknya investor dapat memilih perusahaan dengan prospek yang bagus dan rutin membagikan dividen untuk melakukan investasi. Bagi emiten, sebaiknya dapat mempertimbangkan kebijakan untuk membagikan dividen dan dapat menginformasikan prospek perusahaan di masa depan kepada investor agar investor yakin untuk melakukan investasi pada perusahaan yang membagikan dividen. Bagi penelitian selanjutnya, hendaknya dapat dikembangkan penelitian tentang reaksi pasar terhadap pengumuman cash dividend pada seluruh perusahaan yang terdaftar di Bursa Efek Indonesia (BEI).

\section{REFERENSI}

Andini, N. W. L., Suputra, I. D., \& Wirakusuma, M. G. (2017). Reaksi Harga Saham Saat Pengumuman Dividen Tunai Dimoderasi Oleh Free Cash Flow. E-Jurnal Ekonomi Dan Bisnis Universitas Udayana, 11(1), 4015-4042.

Anwar, S., Singh, S., \& Jain, P. K. (2017). Impact of Cash Dividend Announcements: Evidence from the Indian Manufacturing Companies. Journal of Emerging Market Finance, 16(1), 29-60. https://doi.org/https://doi.org/10.1177/0972652716686238

Aprilia, Y. G., \& Haryanto, A. M. (2017). Analisis Reaksi Harga Saham dan Volume Perdagangan Atas Pengumuman Dividen Kas (Studi Empiris pada Perusahaan yang Listing di Bursa Efek Indonesia Tahun 2013 - 2015). 
Diponegoro Journal Of Management, 6(3), 1-12.

Chaabouni, I. (2017). Impact Of Dividend Announcement On Stock Return:A Study Of Listed Companies In Saudi Arabia Financial Markerts. International Journal of Information, Business and Management, 9(1), 1-13.

Chaudhary, G. M., Hashmi, S. H., \& Younis, A. (2016). Does Dividend Announcement Generate Market Signal? Evidence From Pakistan. International Journal Of Economics And Financial Issues, 6(1), 65-72.

Darmadji, T., \& Fakhruddin, H. M. (2011). Pasar Modal Indonesia: Pendekatan Tanya Jawab. Jakarta: Salemba Empat.

Darmawan. (2018). Dividend Omission Announcement Effect To Market Reaction in Indonesia Stock Exchange. Integrated Journal of Business and Economics, 2(2), 14. https://doi.org/https://doi.org/10.33019/ijbe.v2i2.72

Hannon, A. M. T., Shehadeh, F. H., Jallad, M. N., \& Atir, A. J. I. (2016). Stock Market Reaction To Cash Dividend Announcement: Evidence From Palestine. Research Journal Of Finance And Accounting, 6(1), 20.

Harbi, A., \& Bujang, I. (2016). Dividend Announcements Effects On Stock Market Returns: A Comparative Study Between Conventional And Shari'ah Compliant Stocks On Bursa Malaysia. Journal of Business and Retail Management Research, 11(1), 92-102. https://doi.org/https://doi.org/10.24052/JBRMR/246

Hermuningsih, S. (2012). Pengantar Pasar Modal Indonesia. Yogyakarta: UPP STIM YKPN.

Jogiyanto, H. (2017). Teori Portfolio dan Analisis Investasi. Yogyakarta: BPFE.

Kaur, K. (2018). Dividend Increase Announcement and Stock Price Reaction : CPRA Approach. The IUP Journal of Applied Finance, 24(4), 5-18.

Kayana, F. N., Tommy, P., \& Maramis, J. B. (2018). Reaksi Investor Pasar Modal Indonesia Terhadap Pengumuman Dividen (Studi Kasus Pada Perusahaan Asuransi yang Terdaftar di Bursa Efek Indonesia Tahun 2016 - 2017). Jurnal EMBA, 6(3), 1208-1217.

Kemal, M. U., \& Kashif, S. (2018). Investor's Behavior Towards Dividend Paying Out Firms. Prizren Social Science Journal, 2(2), 12-26.

Kusno, J. I., \& Hartanto, F. T. (2018). Dampak Pengumuman Pembagian Dividen Kas Terhadap Abnormal Return Pada Indeks LQ-45. Jurnal Riset Akuntansi Dan Keuangan, 6(3), 441-452. https://doi.org/https://doi.org/10.17509/jrak.v4i3.4670

Larimanu, I. I. D., \& Suaryana, I. G. N. A. (2015). Reaksi pasar pada pengumuman dividen dengan profitabilitas sebagai pemoderasi di BEI. E-Jurnal Akuntansi Universitas Udayana, 3(1), 803-816. 
Lavista, E., Utami, E. S., \& Puspitasari, N. (2018). Perubahan Abnormal Return dan Volume Perdagangan Pada Hari Sekitar Cum-Dividend Date di Bursa Efek Indonesia. Jurnal Bisnis Dan Manajemen, 12(3), 393-403.

Legenzova, R., Jurakovaite, O., \& Galinskaite, A. (2017). The Analysis of Dividend Announcement Impact on Stock Prices of Baltic Companies. Central European Business Review, 6(1), 61-75. https://doi.org/https://doi.org/10.18267/j.cebr.173

Majanga, B. B. (2015). The Dividend Effect on Stock Price- An Empirical Analysis of Malawi Listed Companies. Accounting and Finance Research, 8(3), 99105. https://doi.org/https://doi.org/10.5430/afr.v4n3p99

Mikluš, M., \& Oplotnik, Z. J. (2016). Capital Market Response to the Change in the Dividend Policy: The Case of Slovenian Stock Market. Research in Applied Economics, 8(1),

42. https://doi.org/https://doi.org/10.5296/rae.v8i1.8839

Mrzygłód, U., \& Nowak, S. (2017). Market Reactions To Dividends Announcements And Payouts. Empirical Evidence From The Warsaw Stock Exchange. Contemporary Economics, 11(2), 187-204. https://doi.org/https://doi.org/10.5709/ce.1897-9254.236

Pramana, K. S., \& Abundanti, N. (2017). Reaksi Pasar Terhadap Pengumuman Dividen di Bursa Efek Indonesia. E-Jurnal Manajemen Unud, 6(11), 63246356.

Rosario, S., \& Chavali, K. (2016). Market Reaction On Dividend Announcement In Oman: An Event Study Methodology. International Journal of Economics and Financial Issues, 6(1), 103-108.

Sartono, A. (2010). Manajemen Keuangan Teori dan Aplikasi (Empat). Yogyakarta: BPFE.

Setiawan, A. R., \& Bandi. (2015). Reaksi Pasar Terhadap Perubahan Dividen Dengan Indikator Abnormal Return dan Trading Volume Activity. Jurnal Economia, 11(1), 1-20.

Stefanus, M., \& Esra, M. A. (2016). Perbedaan Return dan Volume Perdagangan Saham Sebelum dan Sesudah Pengumuman Dividen dan Pengumuman Earning pada Perusahaan yang Terdaftar di BEI Tahun 2016. Manajemen Keuangan, 6(1), 1-20.

Sugiyono. (2013). Metode Penelitian Manajemen. Bandung: Alfabeta.

Tran, Q. T., \& Mai, Y. D. (2015). Stock Market Reaction to Dividend Announcements from a Special Institutional Environment of Vietnamese Stock Market. International Journal of Economics and Finance, 7(9), 50-58. https://doi.org/https://doi.org/10.5539/ijef.v7n9p50

Waweru, F. M., \& Otieno, P. A. (2016). Cash Dividend Change Announcement 
E-Jurnal Manajemen, Vol. 9, No. 3, 2020 : 988-1007

Effect on Share Price Returns: Evidence From Nairobi Securities Exchange. The International Journal of Business and Finance Research, 10(3), 39-47.

Wiagustini, L. P. (2014). Manajemen Keuangan. Denpasar: Udayana University Press.

Widodo, A., \& Nisful, L. (2016). Reaksi Pasar Atas Pengumuman Dividen (Studi Pada Emiten yang Terdaftar di Jakarta Islamic Index). Jurnal Ekonomi Syariah Teori Dan Terapan, 3(2), 85-98. 